\title{
Teaching Writing to Adult English Language Learners: Lessons From the Field
}

\author{
Joy Kreeft Peyton \\ Center for Applied Linguistics, Washington, DC, USA
}

\author{
Kirsten Schaetzel \\ Georgetown University, Washington, DC, USA
}

\begin{abstract}
For the past several decades, it has been clear that the ability to write texts for academic and professional purposes (“academic writing” in this article) is key to the success of adults in U.S. society—in school, in university courses, on tests that they need to take to progress through learning and into work, and in the workforce. Academic writing has specific features and involves approaches that are different from much of the writing that is done with adult learners, particularly those learning English as an additional language (e.g., described in reviews by Hinkel, 2015; Leki, Cumming, \& Silva, 2008; and a survey by Rosenfeld, Courtney, \& Fowles, 2004). However, a recent survey of adult educators, conducted by the authors, found that academic writing has not been a focus in many adult education programs, and teachers receive limited professional development in this area and instructional support in implementing it. This article describes the importance of academic writing at all levels of adult education, the key features of academic writing, and the current state of writing instruction in adult education programs. It then describes the motivation for, design, and outcomes of a survey of and interviews with adult educators across the country on their preparation for and instructional practices with academic writing (conducted in 2014 and 2015). Finally, it describes approaches that can be used in adult education programs to meet the writing proficiency needs of students at all levels and next steps that the adult education field might take.
\end{abstract}

Keywords: academic writing, adult education, adult ESL, English learners, writing instruction

\section{Introduction}

Adult learners of English as a second or additional language need to master a variety of forms of writing, in English, to be successful in their academic and professional endeavors. In an attempt to determine whether these learners are getting the writing instruction they need in adult education programs, we surveyed the field of educators who work with this population. In our survey, we asked teachers of adult English language learners (ESL teachers) in different types of adult education programs in the United States to identify the writing instruction they deliver, including the text types they teach, the amount of time they devote to teaching writing, and the role of writing in student placement and promotion decisions. We then interviewed a subset of the survey respondents, representing a variety of program types, student proficiency levels, and years of teaching experience, to find out more about their specific approaches to writing, the reasons for these approaches, and their views on what they need to be successful as adult educators. After reviewing the importance of academic and professional writing (referred to here as academic writing) in adult English language learners' success, the key features of academic writing, and recent concerns about writing in adult education programs, this article reports the results of 
the survey and the interviews and makes recommendations for future directions in writing instruction in adult English as a second language (ESL) education.

\section{Importance of Academic Writing in Adult Education}

The ability to write texts that clearly state the focus and scope of the topic under discussion, the perspective(s) of the author (and others if appropriate), support for those perspectives, and clear conclusions drawn from the discussion is a critical component of literacy practices in schools, from middle school to high school. This focus has been part of education practice since the 1980s (see, for example, discussion in Spack, 1998; Street, Fox, \& Ellis, 2010), although much writing in schools has focused on narrative texts (Reid, 1993; Shanahan, 2015; Zamel, 1982, 1987). The importance of this type of writing has increased significantly in importance since the introduction of the Common Core State Standards (CCSS) for English Language Arts in many states.

In adult education, similar standards have been introduced through the College and Career Readiness Standards, which aim to equip adult learners for effective participation in academic and workforce settings to attain economic self-sufficiency (Pimentel, 2013; U.S. Department of Education, 2016). In order to achieve these goals, adults need to understand complex processes, be problem solvers, have some degree of computer literacy, and attain both oral and writing fluency in professional English (Casner-Lotto \& Barrington, 2006; Elander et al., 2006; Parrish \& Johnson, 2010). Even many minimum wage jobs, such as taking orders in restaurants, parking cars, or providing security, require workers to use computer software, make independent decisions, and find solutions to problems. These tasks involve high-level language skills, critical thinking skills, computer literacy, and confidence. The College and Career Readiness Standards (CCRS) state clearly what adults in academic, professional, and workforce settings need to be prepared to do: carry out complicated learning tasks, use academic language and complex texts, use evidence from texts to anchor their ideas, and build knowledge through non-fiction works.

In response to this trend, academic writing tasks have been added to some exams used in adult education to determine the postsecondary or workforce readiness of adult learners. For example, the new General Education Development (GED) exam has an academic text-based writing section. The Accuplacer and Compass also have sections devoted to writing, although the most widely administered writing subtests assess grammar, punctuation, and spelling rather than the ability to write extended discourse.

\section{Key Features of Academic Writing}

A number of authors have articulated clearly the key features of academic writing (e.g., Scheiber, 1987; Spack, 1988), which include the ability to

- Create, argue for, and support a thesis statement;

- Use and credit sources;

- Abstract and summarize supporting information;

- Write precisely and concisely using appropriate vocabulary and sentence structure;

- Submit a well-edited piece that is easily understood by a native English-speaking professor;

- Write argumentative, technical, and informative texts.

In order to understand writing requirements in academic contexts (college and university), which many adult learners are seeking to enter, Rosenfeld, Courtney, and Fowles (2004) surveyed professors in Master's and Ph.D. 
programs concerning literacy practices in their fields and disciplines. Their survey focused on what academic literacy practices the GRE should test in order to determine whether a candidate for admission to an MA or Ph.D. program can perform them. Survey respondents rated 36 of the 39 task statements provided as important or very important for entering students to be able to perform competently. The following 12 tasks were rated the highest (Rosenfeld, Courtney, \& Fowles, 2004, pp. 14-15):

1. Credit sources appropriately;

2. Organize ideas and information coherently;

3. Use grammar and syntax that follow the rules of standard written English, avoiding errors that distract the reader or disrupt meaning;

4. Avoid errors in mechanics (e.g., spelling and punctuation);

5. Abstract or summarize essential information (e.g., from speeches, observations, or texts);

6. Analyze and synthesize information from multiple sources;

7. Integrate quoted and referenced material appropriately;

8. Develop a well-focused, well-supported discussion, using relevant reasons and examples;

9. Write clearly, with smooth transitions from one thought to the next;

10. Write precisely and concisely, avoiding vague or empty phrases;

11. Revise and edit text to improve its clarity, coherence, and correctness;

12. Work independently to plan and compose text.

Research in college and university programs for students learning English (e.g., Matsuda, 2006) has found that students receive differing amounts of instruction in these skills in writing courses, even those that focus on academic writing. As Matsuda noted, "In many composition classrooms, ...language issues beyond simple 'grammar' correction are not addressed extensively, even when the assessment of student texts is based at least partly on students' proficiency in the privileged variety of English” (Standard Written English) (Matsuda, 2006, p. 640). If students do not receive this instruction in college composition classes, it is doubtful that they receive it in courses that meet general education requirements or in adult education courses where college and university credit is not granted.

\section{Concerns About Academic Writing in Adult Education}

Given the demands of academic writing and research that demonstrates that it is not always taught in college and university courses, what is the picture in adult education classes? Those who have studied these contexts have found that students are struggling and not always succeeding. For example, Coon (in Coon \& Jacobsen, 2014), concludes, “In my community college work, I noticed that a lot of students were coming in, but many weren’t making it out, just out of the writing courses, and sometimes this derailed their college plans and aspirations completely.” Spurling, Seymour, and Chisman (2008), in a longitudinal study of adult ESL classes in California, found that $56 \%$ of ESL learners in non-credit classes did not advance a single level. An article in The Atlantic (Hulbert, 2014) found that "barely more than a third of community-college enrollees emerge with a certificate or degree within six years."

These challenges are not confined to adult education. A study by the Harvard Graduate School of Higher Education (2011) found that only 56\% of students who begin bachelor's degrees obtain them within six years. Considering this challenge, Hinkel (2004) speculates that students may be stumbling during their general education courses, taken during the first years of a higher education program, because of their lack of academic 
reading and writing skills.

\section{What Are Adult Educators Doing? A Survey of Approaches to Teaching Writing in Adult Education}

In light of the new focus on academic writing in adult education in general and in adult ESL programs specifically and the understanding, from research and our own experience, that academic writing has often not been a focus in these programs, the authors of this article sought to learn whether and in what ways adult learners are currently getting the writing instruction they need to accomplish the goals described here and whether there are ways that adult education stakeholders might work together as a field to help students succeed who "aren’t making it out” of their classes and programs (Coon \& Jacobsen, 2014). To do this, we surveyed adult English as a Second Language (ESL) instructors across the United States, asking them to identify the writing instruction they deliver; the text types they teach; the time they devote to writing; and the importance of writing in student placement decisions in their programs, districts, or states.

The survey consisted of 43 questions, which were a combination of item types: yes/no questions with follow up, drop-down choices, ranking of importance of an area, and four open-ended questions. The survey was first sent (in November, 2014) to listservs that adult educators participate in TESOL's AEIS listserv and the Adult English Language Learners listserv, LINCS Communities of Practice. ${ }^{1}$ Educators were invited to participate in the survey by clicking on an open link. In January, 2015, after a low response rate, we contacted state directors listed on the National Adult Education Professional Development Consortium (NAEPDC) website $^{2}$, who forwarded the invitation to program coordinators at community colleges and community-based organization (CBOs) to disseminate further. As a result of this revised recruitment strategy, $75 \%$ of respondents said that they learned about the survey from their program administrator.

The survey was open until February 1, 2015. Respondents were from 25 states in the United States and Canada, and 96\% were adult educators: $41 \%$ working in community colleges; $63 \%$ part-time instructors, $19 \%$ full-time instructors, $17 \%$ administrators, and $6 \%$ volunteers. Of the total number of respondents, 471 started the survey, and 272 completed it. Most responded to the yes/no, dropdown, and ranking of importance questions, and some did not answer the open-ended questions. Details about the questions asked and rates of responses are reported in Fernandez, Peyton, and Schaetzel (in press). In this article we report on trends in the field that we identified in the responses.

\section{Positive Trends in Place and Emerging in the Field}

The survey responses show a number of positive trends in the field:

- There was overall enthusiasm about participating in the survey (after administrators and teachers knew about it). A strong number responded, and many mentioned that the information collected is important for the field to move forward.

- Many teachers and program administrators recognize that academic writing is important and are shifting their curricula and materials so that that focus is part of instruction. Many reported including writing in their instruction; using a process writing approach, which includes brainstorming, outlining, drafting, revising, and editing; and evaluating and providing feedback on students' writing.

\footnotetext{
${ }^{1}$ See from https://community.lincs.ed.gov.

2 See from http://www.naepdc.org.
} 
- Some programs have taken steps to make clear what expectations are about writing at different English proficiency levels, and some programs include writing proficiency in student placement decisions.

- Some teachers reported having received workshops and other professional development on teaching writing (even though only around $20 \%$ reported having done coursework on teaching writing).

- Some programs offer support for developing students' writing through tutoring centers, volunteer tutors, and career counseling centers.

- Many respondents reported teaching small classes, with 71\% reporting that their classes consist of 15 students or fewer.

- Over half of the respondents reported having classes with the same students three to five days per week, and most classes were held for two to three hours, four days per week.

A focus on writing instruction with institutional support for teachers and students, small classes, sufficient time for classes, and several classes with the same students during a week indicates favorable conditions for teaching academic writing.

\section{Challenges That Programs Face}

At the same time, we found a number of challenges that teachers and administrators still face and misalignments between students' needs in order to be able to engage effectively in academic writing and supports in place to meet those needs.

- Even though teachers had sufficient time with students in classes, most reported spending only one-half hour to one hour per class on writing.

- Most of the writing done was narrative writing, note taking, and descriptive writing (and primarily note taking and grammar exercises at lower levels), with a small amount of technical/instructional and argumentative/persuasive writing. Narrative or imaginary prose was the most common text type reported.

- Primary audiences for the writing were the teacher, fellow students, or themselves (rather than other audiences), and most of the feedback provided focused on specific language features and error correction, done by the teacher. Very few included writer's workshop and other forms of writing feedback in their classes.

- Teachers reported that their program administrators ranked speaking, listening, and reading ahead of writing skills and that this focus is guided by assessments used by states and programs for student placement and program accountability, which focus on listening and reading rather than writing.

- While much of the writing that takes place in academic and professional contexts is done on a computer, most teachers reported that the writing in their classes is done by hand.

- Although teachers reported participating in professional development opportunities (conferences and workshops), few of those focused on academic and professional writing or on developing writing skills of second language learners, and teachers reported limited opportunities to collaborate with other teachers.

\section{Misalignments Between Students' Needs and Program Approaches}

To summarize, we noticed several misalignments in the survey responses between needs that adult learners have to develop their writing proficiency at academic and professional levels and the opportunities that they have in adult education classes (shown in Table 1). 
Table 1

Misalignments Between Learner Needs and Learning Opportunities

\begin{tabular}{lll}
\hline & Needs for Academic and Professional Success & Writing in Adult ESL Classes \\
\hline Types of writing & Argumentative/persuasive and technical/informative texts & Narrative, imaginary, descriptive texts \\
Length of assignments & Paragraph to 10-page paper & Paragraph or less \\
Feedback & On overall ideas and their presentation & Error correction \\
Modality for writing & Word processing & Handwriting \\
\hline
\end{tabular}

\section{What Are Adult Educators Doing? Interviews With Teachers in Programs}

In order to find out more information about approaches to teaching writing in adult education programs, we interviewed a small sample of the teachers who had responded to the survey and who had, in their survey responses, said that they were willing to participate in an interview. The three authors interviewed eleven teachers who worked (at the time of the interviews, Spring 2016) in seven states: Alabama, Arkansas, Iowa, New Mexico, North Carolina, Ohio, Virginia. The programs they taught in were located in community colleges, career centers, regional adult education offices, the public library, and (in one case) a maximum security prison. Many of the classes they taught were non-credit granting, and the programs were either managed enrollment or open-entry/open-exit. Most of the teachers (seven) taught part time, three taught full time, and one was a volunteer. Four taught students at beginning/early levels of English language proficiency (based on the CASAS, TABE CLASS E, and BEST Plus assessments, which are used in adult ESL programs in the United States to place students and determine advancement); three taught students at intermediate and advanced levels; and four taught multi-level classes, with students at many different levels.

These interviews gave us rich insights into challenges that these educators face, instructional practices that they are using, and outcomes they are seeing. They also raised for us some areas in which we as a field can work together, to shift instruction in adult education so that there are more of a focus on engaging adult learners at all levels in academic and professional writing.

\section{Challenges That Teachers Face}

Teachers described a number of challenges that have an impact on their work and effectiveness. These challenges both confirm and expand those identified in the survey responses.

Teacher status and work situations. Most of the teachers work part time (seven of the eleven whom we interviewed), and in many cases, classroom preparation, grading of papers, and collaboration with others are activities that they are not paid to do.

Teacher preparation and collaboration. The teachers interviewed said that they have participated in very little training for teaching writing to adolescent and adult writers and they don't know about forums, workshops, or materials that other teachers or professors in higher education settings participate in or use. When asked if they collaborate with other teachers within or outside of their program, most reported that they have no time for collaboration and primarily teach and plan for instruction alone. They have limited communication with teachers/professors in higher education classes, where their students might transition. Tutors said that they don't feel knowledgeable working with learners on developing writing at academic or professional levels.

Program and classroom focus. The shift in adult education to a focus on higher education and careers has resulted in an increased focus on writing, but there hasn't been this focus in the past, and many teachers 
said they are not prepared for it. There is not enough time in class to dedicate to writing. It's the last priority, and students want to focus on reading and understanding and on listening and speaking skills. In core content classes, the focus is on oral communication, and writing is only done in the writing class, which is a short class that focuses on basic skills. Assessments used by programs and states focus on speaking, listening, and reading and can result in limited writing in classes. One teacher mentioned that since the change in focus of the GED 2014 to academic skills and writing, meeting GED goals has been difficult, "a disaster”.

Funding and resources. Program funding sources may require that students move up a level or get a GED, which not all students need or want and, as described earlier, is difficult to do in brief period of time. When there are funding cuts, external resources for programs are cut back. As a result, programs are struggling for resources. Teachers need to obtain materials, but they are often not able to. Programs may have some recent books and materials, but they need materials for higher levels (levels 2 and 3). Teachers must find free materials on the web, and these focus primarily on basic background information for ESL students and are not geared toward the GED. There is limited computer access in programs, and students need to be prepared to take the GED on a computer.

Student background and knowledge. Teachers described the challenges that they and students face together related to the backgrounds and knowledge that students come with, which are listed here. (The Appendix gives information about the students in the teachers' classes at different levels.)

- Students may have little or no education in their home country and limited experience with taking responsibility for their own learning in class and ways to engage in learning outside the program.

- Students who haven't completed high school may have limited organizational and critical thinking skills and may not know writing conventions, such as length of sentences, use of direct and indirect language, and levels of formality of language in different contexts. They have no knowledge of subject/verb agreement and uses of prepositions and don't know what paragraphs are. They may know what periods are but not that they go at the end of a sentence.

- Some students-including refugees from war-torn countries-are getting over trauma. Even those who have been here for seven or eight years may still be healing. In previous years, many were over-medicated to deal with their trauma. Newer students have difficulty focusing because of trauma they have experienced.

- Students may come into a writing class from core classes, where the aim is to read, speak, and listen and have limited experience with writing and difficulty making the shift.

- Student consistency of participation in the class varies. Many are working and have children. They may come to class, drop out, and come back, miss classes, or arrive late. They are dedicated, but they can't dedicate the time they need to class. Therefore, it is difficult to have all students on the same page. By the end of the class, they all know different things, because they are all there on different days.

- Students may be afraid to write, because they believe they can't write well enough.

\section{Instructional Practices That Teachers Use}

Despite these challenges, the eleven teachers interviewed are dedicated and resourceful, and they were able to articulate clearly the strategies and activities that they are using in their classes to teach writing. Their responses make an interesting set of approaches, which expands considerably on the approaches identified from the survey responses. They are summarized here as lists, the easiest way to process what they described. Many 
of these activities can be used at other levels in addition to the levels in which they are placed here; here we report the approaches that the teachers we interviewed described using at these.

\section{Beginning and low beginning English as a second language (ESL) levels.}

- Dictation: The teacher dictates words or sentences, students repeat aloud and then write.

- Copying: Students copy text written on the board in a notebook. This is often the day of the week or a sentence about a holiday or another topic.

- Learning vocabulary:

$>$ Students look at pictures that include words starting with the letters A-Z and write the words they see.

$>$ Using the Dolch word list of most common English words, students learn the words, learn sentences that include the words, and write the words and sentences. ${ }^{3}$

- Learning grammar: Students do grammar exercises (e.g. in Grammar Step by Step, Robert Dixon, Longman), learn vocabulary in the sentences, and learn to spell the words by writing them on index cards and learning them at home.

- Developing oral language proficiency:

> Students discuss problem-solving scenarios (e.g., they come home to a messy house; What do they do?).

Students describe a picture using different prepositions.

- Building writing from oral language activities: Conversation grids: Students have a sheet of paper with four questions in a column down the left and four student names across the top. They go to four different students in the class, ask each student one of the four questions, and write the answers in the space in the grid (initially with a few words and later in sentences).

- $\quad$ Filling in blanks: Students fill in blanks in sentences with appropriate words, from a sentence or text on the board, in a text they have read together, or a discussion they have had.

- Filling in forms: Students complete registration forms (date, name, middle initial, address, phone number, date of birth), which involves recognizing what is asked for on the form and filling in the needed information.

- Writing notes: Students take notes on a topic discussed in class or a text they have read.

- Writing about something read: Students read Sam and Pat (Books 1 and 2) and write words, sentences, or paragraphs based on topics in the books. ${ }^{4}$

- Learning about opportunities beyond the program: Students attend job fairs held on campus (e.g., when the program is held at a community college).

\section{Multilevel classes.}

As can be seen in the Appendix, all levels of classes have a diverse group of students with a variety of goals for learning. The approaches listed here are those used by teachers that identified their classes as multilevel. They do not differ much from the approaches used by teachers of beginning and low beginning ESL classes.

- Building writing from oral activities:

Students interview each other or the teacher, starting with a form to fill in and moving to more

\footnotetext{
3 See from http://www.dolchword.net/dolch-frequency-word-list.html; http://bogglesworldesl.com/dolch/lists.htm.

${ }^{4}$ See from https://www.amazon.ca/Sam-Pat-Book-Beginning-Reading/dp/1413019641.
} 
complex questions and interviews that lead to a full piece of writing.

- Engaging in activities that focus on components of writing:

> Sentence combining (e.g., using Sentence Combining, a Composing Book, by William Strong. McGraw-Hill. ${ }^{5}$

- Working in groups:

$>$ Write arounds: One student writes a topic sentence, passes the paper to the next person, who writes a supporting sentence, and so on.

Look together at a picture, do a group think aloud, then write.

$>$ Engage in writer's workshop, brainstorming, drafting, revising, editing, and publishing together.

- Writing words and lists: Students keep lists of the activities that they engage in daily.

- Writing with a variety of guidelines or prompts: filling out forms, writing paragraphs in response to a prompt, writing in response to a picture.

- Journal and dialogue journal writing.

- $\quad$ Reading, discussing, and writing poetry, so they can play with language and words.

- Writing descriptions and essays (including those needed for success in college and university).

- Writing emails (e.g., sending messages to the teacher) and letters.

- Writing that requires increasingly more complex sentence structure over time.

- Using available resources: Teachers of multi-level classes described using the following resources:

> Ventures. Cambridge University Press. (six-level, standards-based content-based ESL textbook, which has lesson plans and writing activities)

From Speaking from Writing: Using Oral Skills to Develop Writing, work of Nancy Ferguson, 2012. ${ }^{6}$

Picture-based readers: May have 9-12 pictures on a page, and students write 1 word for each picture.

\section{Intermediate and high intermediate levels.}

- Reading fiction: Students read stories or novels.

- Writing summaries: Students read and write summaries of newspaper or other articles.

- Engaging in pattern recognition: Students are guided to notice language patterns in topics they discuss and texts they read.

- Working in groups to brainstorm ideas, write the ideas, and build a text together.

- Writing essays: The class might start by writing a paragraph a week and then move to writing an essay—descriptions, narratives, and arguments.

- $\quad$ Participating in student writing contests: Students write short pieces (essays, stories), which are compiled in a book. Selected authors go to a ceremony, read their pieces, and receive recognition.

- Engaging in activities beyond the program: Students attend classes offered in the community (e.g., art classes, classes at local museums).

\section{Advanced level.}

- Starting with limited text and building from there, students:

$>$ Write summaries.

Take notes while watching TED talks.

\footnotetext{
${ }^{5}$ See from http://www.amazon.com/Sentence-Combining-A-Composing-Book/dp/0070625352.

${ }^{6}$ See from http://www.docfoc.com/from-speaking-to-writing-using-oral-skills-to-develop-writing-nancy-ferguson.
} 
> Write letters and notes: to a boss, a child's teacher, cover letters for jobs. The teacher might use the first note they write as a preliminary assessment and to guide instructional planning.

Start writing a limited amount of text (e.g., eight lines) and gradually find ways to add ideas, connect the ideas, and develop a comprehensible paragraph.

- Brainstorming and prewriting in class individually (as part of the writing process) or as a group (e.g., everyone has a piece of paper and colored pencils, and they brainstorm and draw and write, building a text together).

- Writing in groups:

> Write arounds: One person in a group writes a topic sentence or a sentence describing something; passes the paper to the next person, who writes the next sentence or draws a picture, and passes the paper to the next person, etc. Then the group works together on the piece. (Teachers described that this alleviates the stress of writing, because individual students are not singled out. It is a group effort.)

$>$ Group-written essays: Students produce their first essay together in groups. They brainstorm together as a group, outline and write the essay together, and then write individually. They might develop the essay over a period of three weeks—-body paragraphs, then introduction, then conclusion. Writing in class ensures that everyone does the assignment and produces something.

> Group sharing: Students write a descriptive essay about their home country, share it with others and learn from each other, and revise their essays based on what they have heard when others shared.

Peer review and editing: Students review and edit each other's pieces.

- Writing in a personal journal or a dialogue journal: Students might write at home or over the weekend, possibly three entries per week. In a dialogue journal, the teacher reads and responds with comments and questions about the content (without correcting), and students have the opportunity to develop ideas with an audience who responds authentically.

- $\quad$ Developing writing from texts read:

> Students write opinion and argumentative pieces based on course readings. (e.g., after reading some articles about public art, students might write about topics such as: Can children appreciate art? How do you view public art in light of the situation in your home country? Do children in your country have access to public art, as they do here?)

Students read poetry, discuss poems, and write poems.

- $\quad$ Providing structure for the writing:

$>$ The teacher writes an idea on the board, and students write about it as much as they can. Their ability to respond to these topics and ideas develops over time.

$>$ The teacher provides guidelines and structures, such as writing frames and graphic organizers, to guide students' writing.

> The teacher provides a structure that starts with personal experience, with features of academic writing. (e.g., Write about your weekend—give a generalization, give specific details, write a conclusion (What do I think now? What do I plan to do next?))

- Connecting writing in the class to work in students' core content classes, using topics for writing that students are studying in their core classes and writing summaries of or opinion pieces about readings in those courses. 
- Giving explicit instruction on grammar and structure, using grammar from the CCCnet web site. ${ }^{7}$

- Using available resources: Teachers described using the following resources with advanced-level students.

$>$ Purdue Owl, with students who want to go to college. ${ }^{8}$

$>$ TEAL (Teachers of English as Additional Language) publications. ${ }^{9}$

$>$ GED preparation materials.

\section{Outcomes Achieved}

The teachers described a number of positive outcomes of these activities:

- $\quad$ Students at beginning levels can now write basic notes, letters, and resumes.

- Students' confidence in their writing and their ability to write has increased. They see that they are improving and have a lot less anxiety than they did when they began. They have opinions about their writing, what they are doing well and why.

- $\quad$ Students are able to catch mistakes in their own writing and in that of others.

- Writing workshop works well, even in multilevel classes, if students feel safe making mistakes.

- Students can work with the questions on the placement test that includes sentence structure (e.g., subordinate and independent clauses).

- $\quad$ Some students manage after one year to pass the community college entrance test.

\section{Lessons Learned From the Interviews: How Teachers Can Build on What They Are Doing}

The list of activities and approaches that the teachers described using at different levels does show a progression from beginning-level to intermediate and advanced levels. We can see development of higher-level, more extensive writing as the levels advance. They also show that in multi-level classes, as the teachers described, there is not much of a focus on writing, because many of the students are interested in oral language development, and the teachers use primarily oral language activities, reading, vocabulary, and grammar.

How do teachers move from what they are currently doing to activities that focus on academic and professional writing? We found during the interviews that this shift is possible. The teachers were eager to talk with us about the approaches they use and were interested in considering ways that they can build on their current approaches to facilitate academic writing development of their students, even if they have not done this in the past (or they were not aware of doing it). For example, some of the teachers of beginning/low-level classes or multilevel classes said that they didn't focus on writing, because their students weren't interested and wanted to talk, listen, and read. However, we would start to hear them talking about times when they actually were engaged in writing. When we mentioned that, they would say, "Oh, that's true. And I also do ..." (another writing activity), and they would describe additional writing that they did. We discovered together that they were engaging students in more writing than they thought they were. When we mentioned even further writing that could be done, they were interested and engaged.

One approach to conversations with teachers at these levels that could build their repertoire of instructional approaches would be to listen to them describe what they are doing and ask:

1. What are students doing (including oral language activities) that builds a foundation for academic and professional writing?

\footnotetext{
${ }^{7}$ See from http://grammar.ccc.commnet.edu/grammar.

8 See from https://owl.english.purdue.edu/owl/.

${ }^{9}$ See from https://www.vu.edu.au/unitsets/EMIEAL.
} 
2. What knowledge, skills, attitudes, experiences, observations, and insights is this activity (or these activities) building on and building toward?

3. Where can this class go with the activities they are engaged in now to build additional knowledge, skills, attitudes, experiences, observations, and insights?

Here we describe three examples that how this might be done with teachers of Beginning and Low Beginning ESL classes and Multilevel classes. This type of reflection can also be done with teachers of Intermediate and Advanced classes, and it would be worthwhile to develop ways to do this (possibly in future publications).

\section{Example 1: Beginning and Low Beginning ESL}

One activity listed above that is used at the beginning level is copying. For example, one teacher described that every morning, students copy in their notebook a simple text that she has written on the board (e.g., "Today is Thursday, February 18, 2016."-a complete sentence about the date, with capital letters and punctuation). After a few weeks, the teacher writes a second sentence as well (e.g., "Today is President's Day." or "The weather today is cold.”) and the students copy both sentences. Initially, after they finished copying, the students simply put their notebooks away. The teacher said that she wanted them to review what they had written, but they usually didn't do that. While we were talking, she realized that after they have done this for a while, some of the students have started to look back at what they had written before in their notebooks and use that writing to help them with what they are writing now. We talked about the skills that the students are developing and next steps they could take as a class.

Skills being developed. Two skills critical to academic/professional writing are being developed with this simple copying activity: 1) Metalinguistic awareness (awareness of what I am doing now and of what resources I have available that can support what I am doing) and 2) Use of print resources to guide production of print. Students are realizing that they have available to them print resources (their own writing) that can help them produce the next piece of writing.

Other activities the class could do to promote academic writing ability. After this realization, of the important skills that are being developed, the teacher started to talk about other things that the class could do that would build from this activity. For example:

- Use specific days (e.g., Presidents Day) to talk about and write notes about the President, 4-year Presidential terms, elections, and current events.

- Start to focus on specific vocabulary, and representation of sounds and other language features, in the texts that the students copy.

A group of teachers of students at this level discussing this example together would probably come up with many more ideas.

\section{Example 2: Beginning and Low Beginning ESL}

Another activity listed above that is used at this level is Conversation Grids, which the teacher who described it considered to be an oral language activity. At least once a month, students are given a sheet of paper with four questions in a column to the left and four student names across the top. Each student goes to four different students, asks one of the four questions of each student, and writes the answers in the space in the grid. About halfway through the year (when the interview took place), they were writing the answers in complete sentences. The students are given new questions each time, aligned with what the class is studying at 
the time, and after they have collected their information, they share with the class what they have learned.

Skills being developed. Clearly the students are not only speaking and listening but also reading, writing, gathering information from different sources, and reporting and reflecting on that information.

Other activities the class could do to promote academic writing ability. There are a number of different ways that this activity can be expanded to further students' academic thinking and writing abilities:

- Students could talk about and write answers to one question that they ask four students, with the whole class focusing on that one question. They could then review and compare the responses they received, discuss as a class what they have learned, synthesize the information, and discuss and write about the multiple perspectives that they have gathered on the question or topic.

- They could select a topic themselves and develop a set of questions they would like to know about that topic, collect student answers to the questions, and give a talk on the topic or write a paper about it based on what they have learned.

- Instead of getting a simple answer to a question, they could interview each other at length about an experience, topic, or issue that the question raises.

- They could together develop a bar graph or chart of all students' responses to a specific question and then write a paragraph (together or alone) describing the information in the graph or chart.

\section{Example 3: Multilevel Class}

It is clear from the interviews that multilevel classes can present a challenge for teachers seeking to engage in academic writing. One way that teachers described addressing this was to develop group activities, where students at different levels, and with different knowledge and language proficiencies, support and guide each other. One such activity is a write around: One student has a piece of paper; writes a thought, or a sentence, or a topic sentence; and passes it on to the next student. (The idea or sentence might grow out of a text or set of texts the class has read or a discussion they have had.) The second student writes a word or a sentence or draws a picture (depending on their proficiency level) that builds on the idea expressed and passes it to the next student. The group keeps writing and passing the paper until time is up.

Skills being developed. Students are engaging in a number of activities needed in academic writing, including formulating in writing (or a picture) an idea based on what has been read or discussed earlier, understanding what has been written or drawn, and formulating a related idea.

Other activities the class could do to promote academic writing ability. Again, there are a number of ways that this activity can grow into rich, high-level academic writing, even in a class with different proficiency levels.

- After passing the paper and writing or drawing for a few rounds, each group could start to look at what they have written and talk about what they might develop together, reviewing the focus of the piece, developing paragraphs in the body, and then writing an introduction and a conclusion. They could share with the class or another group what they have written, discuss more ideas that they might add, and revise and edit the paper together as a group, looking for specific features that the teacher assigns or that they decide to focus on.

- The teacher could provide frameworks or rubrics that would guide the groups and help them to be more focused in their writing. One framework that is helpful for building the focus of a piece of writing is 
RAFT, which is described on a number of web pages. ${ }^{10}$

$\mathbf{R}=$ Role (Who am I as a writer?)

$\mathbf{A}=$ Audience (To whom am I writing?)

$\mathbf{F}=$ Format (What form will the writing take?)

$\mathbf{T}=$ Topic (What is the subject?)

Calderón, Carreón, Slakk, and Peyton (2015) give an example of what these might look like in different writing activities (see Table 2), which would be adjusted by the teacher and the students depending on student interests and levels and the focus of the class, unit, or lesson.

Table 2

Example RAFT Components (Calderón, Carreón, Slakk, \& Peyton, 2015)

\begin{tabular}{llll}
\hline $\mathrm{R}$ & $\mathrm{A}$ & $\mathrm{F}$ & $\mathrm{T}$ \\
\hline News reporter & College-educated adults & News article & Global warming \\
Astronomer & First graders & Travel guide & Journey through the solar system \\
Acute triangle & Obtuse triangle & Letter & Differences among triangles \\
Jackie Robinson & Hall of Fame audience & Acceptance speech & My life in baseball \\
Tornado tracker & Weather reporter & Interview & Facts about tornados \\
Hermione Granger & Harry Potter & Dialogue & Why are you so suspicious? \\
Rosa Parks & Historians & Diary entry & The boycott \\
\hline
\end{tabular}

These are three examples, but there are many ways, at all levels of student proficiency, that teachers can raise the level and quality of students' writing by 1 ) understanding what they and their students are doing now that might build a foundation for academic and professional writing; 2) building student knowledge about the activity, topic, or text(s) through discussion, group work, reading of other texts, and providing guidance and rubrics; and 3) considering what the class might engage in next, given what we know about the requirements of this type of writing.

\section{Conclusion and Recommendations: Next Steps for the Field}

The review of the literature on shifts in educational focus to academic and professional writing and the survey of and interviews with professionals working in adult ESL education have shown us that academic writing has clearly understood features and requirements, this type of writing has not been a strong focus in adult ESL education in the United States, and there are a number of ways that we as a field could work with teachers to help them make the necessary shift. The following are some of the steps that we might take as a field:

- Conduct similar surveys and interviews in different states. One of the authors of this article (Rebeca Fernandez) conducted the national survey with adult education teachers in North Carolina (in the Spring 2016). Many of the national trends were similar, but there were also trends specific to teachers in that state. A survey of teachers across a state, followed by in-depth interviews (similar to those that we conducted), would allow us to understand and provide support for teachers in a more focused way. All states and many school districts and community colleges hold professional conferences for adult education teachers. Results of such surveys and interviews could inform those professional development opportunities

\footnotetext{
${ }^{10}$ See from http://www.readwritethink.org/files/resources/printouts/RAFTWriting.pdf; http://www.readwritethink.org/professional-development/strategy-guides/using-raft-writing-strategy-30625.html.
} 
significantly.

- $\quad$ Building on these efforts, identify and disseminate promising practices in terms of time spent writing, text types that students write, audiences that students write for, types of feedback given, types of assessments used, and ways that one type and level of activity can be used to build the next types and levels.

- Work with teachers, program administrators, and state leaders to articulate writing proficiency expectations (aligned with writing practices in university courses), ways to reach those expectations at each student proficiency level, and ways to assess student achievement.

- Coordinate instructional approaches across student proficiency and class levels, so that students build from level to level in a sustained, consistent way.

- $\quad$ Include effective writing in student placement and advancement decisions.

- $\quad$ Put more of a focus on academic and professional writing at local, state, and national levels that are aligned with writing components of college and career readiness standards.

- $\quad$ Ensure that teachers have opportunities to participate in professional development opportunities, learning communities, and collaborations that have this focus.

There is a great deal to be done in the field of adult ESL education to ensure that learners in adult education programs are learning to do what they need to do to be successful in further education and work. Educators are clearly interested in participating in needed changes, but they cannot do it alone. It is time for us to work together as a field to make the needed shifts.

\section{References}

Common Core State Standards Initiative. (2016). English language arts standards. Retrieved from http://www.corestandards.org/ELA-Literacy/

Calderón, M. E., Carreón, A., Slakk, S., \& Peyton, J. K. (2015). Expediting comprehension for English language learners (ExC-ELL) foundations manual. New Rochelle, NY: Benchmark Education.

Casner-Lotto, J., \& Barrington, I. (2006). Are they really ready to work? Employers' perspectives on the basic knowledge and applied skills of new entrants to the 21st century U.S. workforce. New York, NY: The Conference Board. Retrieved from http://www.p21.org/storage/documents/FINAL_REPORT_PDF09-29-06.pdf

Coon, D. A., \& Jacobsen, N. (2014). Community college writing programs: Defining success for the immigrant student population. Washington, DC: Center for Applied Linguistics.

Elander, J., Harrington, K., Norton, L., Robinson, H., \& Reddy, P. (2006). Complex skills and academic writing: A review of evidence about the types of learning required to meet core assessment criteria. Assessment \& Evaluation in Higher Education, 31(1).

Fernandez, R., Peyton, J. K., \& Schaetzel, K. (in press). A survey of writing instruction in adult ESL programs: Are teaching practices meeting adult learner needs? COABE Journal.

Harvard Graduate School of Education. (2011). Pathways to prosperity: Meeting the challenges of preparing young Americans for the 21st century. Retrieved from http://www.sawdc.com/media/5959/pathways_to_prosperity_feb2011.pdf

Hinkel, E. (2004). Teaching academic ESL writing—Practical techniques in vocabulary and grammar. New York: Routledge.

Hinkel, E. (2015). Effective curriculum for teaching L2 writing: Principles and techniques. New York, NY: Routledge.

Hulbert, A. (2014, January/February). How to escape the community college trap. The Atlantic. Retrieved from http://www.theatlantic.com/magazine/archive/2014/01/how-to-escape-the-community-college-trap/355745/

Leki, I., Cumming, A., \& Silva, T. (2008). A synthesis of research on second language writing in English. New York: Routledge.

Matsuda, K. (2006). The myth of linguistic homogeneity in U.S. college composition. College English, 68(6), 637-651.

Parrish, B., \& Johnson, K. (2010). Promoting learner transitions to postsecondary education and work: Developing academic readiness skills from the beginning. Washington, DC: Center for Applied Linguistics. Retrieved fromhttp://www.cal.org/caelanetwork/pdfs/TransitionsFinalWeb.pdf

Pimentel, S. (2013). College and Career Readiness Standards for adult education. Washington, DC: MPR Associates, Inc. 
Retrieved from https://www.vrae.org/images/customer-files/CCRStandardsAdultEd.pdf

Reid, J. (1993). Teaching ESL writing. Englewood Cliffs, NJ: Prentice Hall.

Rosenfeld, M., Courtney, R., \& Fowles, M. (2004). Identifying the writing tasks important for academic success at the undergraduate and graduate levels. (GRE Board Research Report No. 00-04 R). Princeton, NJ: Educational Testing Service. Retrieved from https://www.ets.org/Media/Research/pdf/RR-04-42.pdf

Scheiber, H. J. (1987). Toward a text-based pedagogy in the freshman composition course-With two process-oriented writing tasks. Freshman English News, 15, 15-18.

Shanahan, C. (2015). Disciplinary literacy strategies in content area classrooms. ILA E-ssentials. Newark, DE: International Literacy Association.

Spack, R. (1988). Initiating ESL students into the academic discourse community: How far should we go? TESOL Quarterly, 22(1), 29-51.

Spurling, S., Seymour, S., \& Chisman, F. P. (2008). Pathways and outcomes: Tracking ESL student performance: A longitudinal study of adult ESL service at City College of San Francisco. Council for the Advancement of Adult Literacy. Retrieved from http://eric.ed.gov/?id=ED506600

Street, B., Fox, V., \& Ellis, V. (2010). Rethinking English in schools: Towards a new and constructive stage. New York: Bloomsbury.

U.S. Department of Education. (2016). Integrated English literacy and civics education under the workforce innovation and opportunity act-Frequently asked questions. Washington, DC: Office of Career, Technical, and Adult Education. http://www2.ed.gov/about/offices/list/ovae/pi/AdultEd/octae-program-memo-15-7-ielce.pdf

Zamel, V. (1982). Writing: The process of discovering meaning. TESOL Quarterly, 16(2), 195-210.

Zamel, V. (1987). Recent research on writing pedagogy. TESOL Quarterly, 21(4), 697-715.

\section{Appendix: Students in Classes of Teachers Interviewed: Backgrounds and Interests}

\section{Levels 1 and 2: Beginning ESL Literacy (based on the CASAS test) \\ Low Beginning ESL (TABE CLASS E and BEST Plus)}

May include:

- Primarily women, who want to communicate with teachers, neighbors, and their children

- $\quad$ Elderly people, who want to communicate with teachers, neighbors, and their children and grandchildren

- $\quad$ May have a job or be looking for a job but often are not

- $\quad$ Some are interested in seeking citizenship

- $\quad$ May be newly arrived, have college degrees, and are waiting for their year of residency

- May have been in the country a long time, are working, and now have the opportunity to go back to school

- $\quad$ Some young students in their 20s, who are 1.5 generation or have attended very little school (could be from as diverse places as China or Central America). Are learning to speak very quickly.

- $\quad$ Are often more focused on oral communication (listening and speaking) than on reading and writing.

- Don't necessarily have academic or career goals

\section{Multilevel Classes}

There could be one or a few students at every level described here. These are the different student goals described by the teachers.

- Want to survive in English-speaking society

- $\quad$ Are at an ESL literacy level and are fluent in spoken English but not in text or academic literacy

- Were in grades K-12 until age 22 but prefer not to be with younger students

- $\quad$ Are in a GED class or want to be in one

- Come for ESL/Civics instruction because they want to be citizens and want to know how U.S. elections and the American political system work

- $\quad$ Potential DACA beneficiaries who are beginning to consider college 
- Want a career certificate

- Want to model interest in learning and education for their children

- $\quad$ According to the teachers of these classes, only a few are currently focused on making a transition to college.

\section{Intermediate to High Intermediate}

Students want to ...

- Go to college

- Get a GED so they can go to college

- Get a job, a better job, or a better paying job (in a restaurant, as kitchen or wait staff, truck driver, secretarial, minimum wage with good hours or a job in the field they were working in in their home country). They may leave the class as soon as they get a job.

- Get a certificate

- $\quad$ Seek their own improvement for a number of reasons, including helping their children

\section{Advanced}

- $\quad$ Some students want basic communication and to build confidence to get a better, higher-paying job.

- Some want to develop life skills, write and speak clearly and with proper syntax, or reduce their accent.

- $\quad$ Some have advanced degrees and want to improve their skills to get jobs, with additional training and certifications.

- $\quad$ Some never completed high school and want to get a GED.

- Younger students are trying to get into community colleges, and they may not have passed the placement test for the community college (e.g., the test in Virginia has reading and math sections and all students, degree-seeking or not, have to pass both sections to take any courses at community colleges). 